Zbigniew Machelski*

\title{
The system of government and the opposition in Poland after the 2015 parliamentary elections
}

Keywords: populism, government, democratic system, veto points

\begin{abstract}
The category of the system of government in Poland requires reference to 'the governance style' of the right, and to the tendency that has appeared in international politics in recent years to call it populist nationalism. The objective of this paper is to show that in the case of Poland after 2015, the thesis of the retreat of democracy has no factual grounds, and it can be countered through the use of evidence. The system of government in Poland after the Law and Justice party came to power cannot be described as a contradiction to democracy. Citizens are not being manipulated and deceived. They are aware of the content of decisions made by the executive branch. The opposition is able to act freely, and it is supported by independent private media. There are many veto points in the political system. The government can count on public support that is stronger than that of the governments from the period before 2015.
\end{abstract}

* ORCID ID: https://orcid.org/0000-0001-8663-1177; Opole University, political scientist, professor of humanities, head of the Chair of Political Systems in the Institute of Political Science and Administration at the Faculty of Political Science and Social Communication of the University of Opole. He deals with the issues of parliamentary opposition, territorial structures of a state, government systems and history of political institutions. Works on the political system of the Italian Republic take a special place in his scientific background. $\mathrm{He}$ is an author of seven monographs, three papers under editorship and over one hundred reviewed scientific articles in Polish and foreign journals. Email: zmachelski@uni.opole.pl 


\section{Introduction}

The system of government, indicated in the title, will be understood as a set of formal procedures, informal rules and behaviours setting normative and actual relations among constitutional entities of legislative, executive and judicial powers. It also regards the relations between the government majority and the opposition that will require reference to 'the governance style' of the right, and to the tendency that has appeared in international politics in recent years to call it 'populist nationalism'. This asserts the conviction that aim of populist leaders is to firstly strengthen their grip on the power they achieved legitimately in democratic elections, and - secondly - they undermine the mechanisms of control and balance by influencing the activity of courts and independent media. This is the basis of why Jarosław Kaczyński, leader of Prawo i Sprawiedliwość (PiS) (Law and Justice), who formed a government after winning the parliamentary elections in 2015, is included within the same category of politicians as Vladimir Putin from Russia, Recep Tayyip Erdoĝan from Turkey and Viktor Orbán from Hungary. This is accompanied by the claim that democracy is in retreat in Poland. The aim of the present article is to show that this hypothesis has no objective basis, and it has been falsely based on contradictory evidence. The work methodology of the paper is based on factor analysis, which is useful in building scales composed of many positions to measure abstract concepts, and on comparative analysis connected with an empirical approach relating to an actual 'objective' observation of the phenomena. It was assumed that the government system consists of theoretical (constitutional) projects, but also (or, in fact, first of all) of the practice of their application. Reference to the elements of micro-theory of the political style and models of political leadership is of practical importance.

\section{The dimensions of rationalization of the governance system - introduction}

One of the most important problems of transition from authoritarianism to democracy is the selection of an optimal political system (governance system). It is connected with the necessity of choosing between 
parliamentarism, presidentialism or semi-presidentialism ${ }^{1}$. These categories are used by the representatives of constitutional law and political sciences during the analysis of the system of government. Proper synergy between the normative and politological approaches is to be sought in this process. Of fundamental importance to comparative studies is the criterion of the distribution of political power between the legislative and the executive, which makes it possible to divide democratic systems of government into two basic groups: based on cooperation (fused-powers systems) and those whose basis is separation (separation-ofpowers systems $)^{2}$. The first case is a characteristic of parliamentarism, while the other is associated with presidentialism. Parliamentarism has never been an intricate theoretical construction. The American version of Presidentialism was established in clear opposition to the English solution. Other European solutions, except for the tradition of federal states in ancient Greece and in Switzerland, were rejected by the Founding Fathers. As a consequence, a system was created where the nation is the highest authority. People are the real rulers and even their passions, "cannot encounter any permanent obstacles which would make it difficult for them to affect the course of public matters" 3 . The design of this kind of political system affected the process of the rationalization of the parliamentary system in Europe. Initially, the term 'rationalization' was understood as the juridization of the system mechanisms which sort to counteract possible pathological deviations. As a result, it turned out that the parliamentary system has two versions, namely the traditional, i.e. dualist version with the parliament functioning as the balance in the relationship between the legislative and the executive, and the monistic one. The first assumes the mutual offsetting of both powers. This was additionally guaranteed by symmetrical bicameralism, where the head of state (possibly refusing his sanction against the act) decided in the same way as both chambers on whether or not the proposed regulation would come to fruition ${ }^{4}$. These principles created a canon of the parliamentary

1 A. Antoszewski, System polityczny RP, Warszawa 2012, p. 47; C. Pinelli, Cambiamento o razionalizzazione della forma di governo, [in:] M. Volpi (ed.), Istituzioni e sistema politico in Italia: bilancio di un ventennio, Bologna 2015, p. 75.

2 A. Antoszewski, Metodologiczne aspekty badan nad systemami rzadzenia, [in:] J. Szymanek (ed.), System rząów w perspektywie porównawczej, Warszawa 2014, pp. 15-16; G. Pitruzzella, Forme di governo e trasformazioni della politica, Roma-Bari 1996, p. 21.

3 A. de Tocqueville, O demokracji $w$ Ameryce, vol I, transl. Barbara Janicka, Marcin Król, Kraków-Warszawa 1996, p. 175.

4 J. Szymanek, Mechanizm racjonalizacji parlamentarnego systemu rządów: przegląd koncepcji, [in:] J. Szymanek (red.), System rząów..., p. 164. 
system until its mutated form appeared, which was monistic parliamentarianism. The basis of all versions (models) of the democratic system are elections. Their effect is that the people have exclusive "possibility of accepting or refusing to accept those who are expected to govern" ${ }^{5}$. This introduces the reader to different concepts of democracy ${ }^{6}$ and allows for a question to be posed regarding what democracy means today. The system of government in Poland after 1989 fits the two-element (dualist) system of the executive. The adopted solutions are not, however, classical 'parliamentarism'. The executive branch consists of a government with a prime minister, as well as the President of the Republic of Poland, who is elected by universal suffrage. Art. 10, item 2 of the Basic law from 2 April 1997 decides expressis verbis that the executive power is vested in the President of the Republic of Poland and the Council of Ministers ${ }^{7}$. The opponents of this unambiguous classification assume that in reality the president carries out the executive power to the smallest degree and his/her constitutional profile focuses on the functions which follow from art. 126 of the Constitution. They assume that the Basic law envisages neutral power for the president as a guarantor of the continuity of state authority, who safeguards the state's sovereignty and security ${ }^{8}$. The monistic system is characterized by a few features. The first one is a principal asymmetry of powers which presents a clear advantage to the legislative. Secondly, it eliminates all solutions that violate the exposed status of parliament. Thirdly, it is characterized by marginalization of the political position of the head of state in the system of government. The centre of gravity in the system of power is shifted to the cabinet.

An important factor that has impact on the political and constitutional legitimacy of the President of the Republic of Poland is the independence in decision-making and the capacity to undertake "arbitration" actions ${ }^{9}$. It is directly conditioned by "its legitimation (independent from the position or assessments formulated by other organs of the state) and

5 J.A. Schumpeter, Kapitalizm, socjalizm, demokracja, transl. Michał Rusiński, Warszawa 2009, p. 355.

6 D. Held, Modele demokracji, transl. Wojciech Nowicki, Kraków 2010, pp. XIII ff.

7 Z. Witkowski, W. Woźniak, Remarks on the contents of the power of pardon in the light, [in:] Z. Witkowski, J. Jirásek, K. Skotnicki, M. Serowaniec (ed.), Wspótczesne problemy sadownictwa w Republice Czeskiej i w Rzeczypospolitej Polskiej, Torun 2017, p. 35.

8 A. Chorążewska, Model prezydentury $w$ praktyce politycznej po wejściu $w$ życie Konstytucji RP $z 1997$ r., Warszawa 2008, pp. 31-32 ff.

9 M. Grzybowski, Prezydencki arbitra $\dot{z}$ polityczny: uwarunkowania wyborcze $i$ ustrojowe, [in:] B. Szmulik, J. Szymanek (ed.), Interpretacje i reinterpretacje podziału władzy, Warszawa 2020, p. 101. 
the accompanying stability of the principle of rotation in office which is not threatened by cassation. A parliamentary system shaped in this way is becoming the starting point for rationalization measures. Rationalization in this case means the strengthening of the position of the executive with strong competences, while remaining within the dualist solution in the system of government. This requires a clear line of demarcation to be drawn between its collegial organ (government) and the head of state. An example of this system is the political practice of Westminster parliamentarism, where everything that can cause political destabilization, once a synonym of monistic parliamentarism, was reduced. The Constitution of the Republic of Poland from 1997 provided not so much the model of a bicameral parliament, but two organs of the state which realize the executive power. This is confirmed by the title of Chapter IV of the Basic law and its detailed content. However, the adopted formula of bicameralism is not clear. It is a continuation of the model established in the 'small constitution' from 1992. The solution adopted then was the extension of the 'round table' compromise from 1989, when a bicameral parliamentary system was accepted with the clear depreciation of the Senate, which was perceived as the specific 'price' for its fully democratic election ${ }^{10}$. The rationalization of the parliamentary system can be also viewed as enforcing a two-party or two-block system of political competition, assuming that the real parliamentary system is inseparably correlated with a two-part system ${ }^{11}$. This is the reason why the disappearance of the two-part system on the one hand, and a weakened inter-party discipline on the other may be viewed as a symptom of a crisis in the parliamentary system. It is also worth noting that excessive 'manipulation' of the political placements for the executive in the process of the rationalization of the parliamentary system of government often leads to a conflict in the scheme of competitive executive which the parliamentary system did not foresee. The first level of conflict refers to the institutional sphere between the head of state and the government as two separate entities of the executive power. The second level can have a personal character, and it can be manifested on the axis of competition between the office of the head of state and the leader of the collegial organ of the executive (government). The third level is political and is

10 Konstytucja Rzeczypospolitej Polskiej, wprowadzenie B. Szmulika i J. Szymanka, Warszawa 2017, p. 51.

11 A. Mastropaolo, L. Verzichelli, Il parlamento. Le assemblee legislative nelle democrazie contemporanee, Roma-Bari 2006, pp. 151-152. 
determined by the distinctiveness of the political parties behind each segment of the executive power.

National identity conditioned by four basic historical processes has a particular impact on the development of contemporary government systems ${ }^{12}$. The first one is the population transfer across political borders or the sending of settlers to new territories. This is sometimes accompanied by ethnic cleansing. The second process leading to the shaping of nationality is the shifting the borders, so that they will correspond to the areas inhabited by a homogenous group of people i.e. language and culture. This is how the unification of Italy and Germany was achieved in the 1860's and the 1870's. The third process is the cultural assimilation of minority populations with an existing ethnic or language group. The fourth process is shaping the national identity in such a way that it fits the existing features of a given society within a specific state, the example being Ukraine since 1991. Thus, according to Angelo Panebianco, a number of new neo-nationalist movements and parties (called souverainists) can be compared to the totalitarian parties of the past (fascists and communists) ${ }^{13}$. This does not reduce the basic task of every government system, which is to shape national consciousness in such a way that a nation aware of its distinctness fits into a diverse international community. The division into souverainists supporting national sovereignty and the supporters of European sovereignty provides a presumption of right-wing and left-wing populism emergence ${ }^{14}$. This impinges on the political system of the European Union (the EU) where there is a clearly emphasised tendency regarding such actions and behaviours that are managed through instructions, regulations and decisions issued by the supervisor, meaning [...] to vertical interactions" 15 . Because the EU is still a relatively young creation, and it has not yet achieved the desired status of a political power, it considers its greatest success to be the Nice Charter of Fundamental Rights from 2000 , which fits a broader range of activities in defense of human rights and lawfulness that also has influence on the systems of government of

12 F. Fukuyama, Tożsamość. Wspótczesna polityka tożsamościowa i walka o uznanie, transl. Jan Pyka, Poznań 2019, pp. 174-175.

13 Referring to the nation (people), they, 'question traditional western rooting of their countries'. A. Panebianco, Le cadute in politica Estera, https://www.corriere.it/opinioni/19_novembre_27/nostra-difficile-democrazia (29.11.2019); cf. S. Levitsky, L. Way, The Myth of Democratic Recession, «Journal of Democracy» 2015, vol. 26, No. 1, pp. 45 ff.

14 Ch. Mouffe, Per un populismo di sinistra, Bari-Roma 2018, p. 82.

15 J. Ruszkowski, Ponadnarodowość w systemie politycznym Unii Europejskiej, Warszawa 2010, p. 392. 
member states. An example of this may be the dispute on the rule of law in Poland after 2015.

\section{Opposition and veto points}

The existence and activity of an opposition is certainly the main feature of the democratic system of government, which requires competition between political parties with differentiated social and political programs and alternation (exchange) of the teams which exercises power in the country ${ }^{16}$. The opposition has a close relation to political parties and to the division of power between the government and the parliament within its functions and competences. Modern constitutionalism is based on the principle of political representation accentuating the importance of the parliament as an arena for the formation of political decisions. That is why, we expect that institutions sometimes appropriated by party demagogues and lobbyists be the embodiment of the rule of law ${ }^{17}$. It is not a new problem. It was already noticed long ago that Montesquieu's analysis of the competences belonging to the executive and the legislative was neither fully systematic nor fully coherent ${ }^{18}$. In Western literature, many authors believe that "all doctrinal proposals of, e.g. Lock, Montesquieu or Constant do not currently make much sense as a matter that determines the principal division of power [...], which is the striving for its limitation, is the division onto the power of the government and opposition"19. Montesquieu made a differentiation between "the power of enactment" and "ability to interfere" - he wrote that: "In every government there are three sorts of powers: legislative power; the executive in respect to things dependent on the law of nations; and the executive in regard to matters that depend on the civil law. [...] the last one can be called the power of judging, and the second simply the execu-

16 S. Bożyk, Opozycja parlamentarna w Sejmie RP, Warszawa 2005, pp. 10-11.

17 J. Zaleśny, Kontrola konstytucyjności prawa: nowa aranżacja podziału władzy, [in:] B. Szmulik, J. Szymanek (eds.), Interpretacje..., p. 167.

18 However, the French philosopher, lawyer and writer of the Enlightenment did this in a very profound manner and his findings are still the definitive academic text on the state's organs and the relations between them. Cf. e.g. A. Burda, Doktryna konstytucyjna Monteskiusza, [in:] J. Bardach, K. Grzybowski (eds.), Monteskiusz i jego dzieło, Wrocław 1956, pp. 186 ff.; L. Nowak, Podziat władzy w historii myśli politycznej - wybrane problemy, [in:] B. Szmulik, J. Szymanek (eds.), Interpretacje..., pp. 48-52.

19 B. Szmulik, J. Szymanek, Podziat władzy: interpretacje i reinterpretacje, [in:] B. Szmulik, J. Szymanek (eds.), Interpretacje..., p. 10. 
tive power of the state"20. The first lies within the domain of parliament, and this is where the opposition appears to present alternative solutions. That is the reason why it is treated as an integral part of the process of power. Opposition is defined as an ordered set of asymmetrical social relations making it possible for definite entities to undertake and realize the decisions of producing and distributing public goods. It participates in the free game of forces in accordance with the rules of the democratic system, constructing a program and personal alternative to the ruling parties within the frames of a democratic institutional mechanism that enforces the social and political dialogue ${ }^{21}$. The opposition as a political party enables influencing the shaping of state decisions according to the range of social support it received in democratic elections ${ }^{22}$. Not every parliamentary party which has a negative attitude to the government can be qualified as opposition. Therefore, we can distinguish the 'political opposition' from behaviour that results in the contestation or actual resistance against those in rule in the form of 'civil disobedience', literally understood 'fight for power', 'civil war'23, or other similar behaviour designed to destabilize the system of government. The right to opposition is connected with a strong sense of and attachment to individual freedom. This does not mean much to an individual if it is not associated with the right to freely express and represent his or her views, which do not enjoy the approval of the majority. If, however, the majority makes excessive use of the possessed possibilities at the cost of the minority, the risk is the lowering of the efficiency of the system of government and of the level of acceptance of the political system. This mechanism, which works both ways, is the starting point for the description of various ways of justifying democracy and the process of de-democratization ${ }^{24}$. This also allows for the explanation of two basic models of opposition: conflict-based and compromise-based viewed in the categories of the regime of confrontational opposition and concilia-

20 Monteskiusz, O duchu praw, transl. Tadeusz Boy-Żeleński, Kraków 2003, pp. 148-149.

21 R. Dahl (ed.), Political Oppositions in Western Democracies, New Haven-London 1966; G. Rizzoni, Oposizione parlamentare e democrazia deliberativa. Ordinamenti europei a confronto, Bologna 2012; K. Pałecki, Opozycja polityczna - próba typologii, [in:] K. Łabędź (ed.), Rola opozycji w systemach demokratycznych, Kraków 2016.

22 E. Zwierzchowski, Opozycja parlamentarna, [in:] E. Zwierzchowski (ed.), Opozycja parlamentarna, Warszawa 2010, p. 10.

23 K. Pałecki, Opozycja..., p. 9; I write about it in: Opozycja polityczna w Europie. Ujęcie porównawcze, Warszawa 2016.

24 I. Shapiro, Stan teorii demokracji, transl. Izabela Kisilowska, Warszawa 2006; Ch. Tilly, Demokracja, transl. Michał Szczubiałka, Warszawa 2008. 
tory or cooperative opposition ${ }^{25}$. The first model, in accordance with the concept of antagonistic parliamentary, was created and occurs in Great Britain where the government and the opposition are two political forces constantly fighting against each other. Their mutual relations are based on three assumptions: competition aimed to obtain the power, tolerance when it is exercised and a change of those in power conducted as a result of universal elections. The opposition is not involved in the processes of governing the state; it is only the necessary second side of the parliamentary system of government, a symmetrical and equal counterpart of the government majority. The second model of opposition occurring in the majority of European countries regards partial compromise, and its inclusion in the processes of exercising power. An example of the cooperative style of opposition can be observed in the Bundestag ${ }^{26}$. We usually say that it is a model of constructive opposition. The models of opposition are connected with the manner of public policy change. According to George Tsebelis, the performance of this task is easier when the number of veto players (veto points) decreases, and their inherent coherence increases and the political distance between the players gets smaller ${ }^{27}$. This leads to the level of game theory, which is used during the analysis of the decision-making processes. It is assumed that it is advantageous in the game to possess 'veto points' (institutional obstacles and political brakes). They make it possible to 'play with veto' (veto players), the stake being a change in the status quo. Of key importance in the game is having the agreement of institutional veto players ${ }^{28}$. This means that an important player has the ability to prevent a change in the status quo, excluding the situation when all the players have decided unanimously that some changes should take place. Victory is achieved by the "teams" with the greatest strength measured by the size and efficiency of the organization, access to knowledge, and wealth, meaning qualities that make some players cope with some issue better than others. This is fostered by various circumstances and factors, such as the number of political parties, the properties of the party system, the size of electoral support for radical groups, and the activity

25 E. Zwierzchowski, Opozycja..., p. 21; G. Pitruzzella, Forme..., p. 232.

26 A. Missiroli, I «governi» dell'opposizione: Gran Bretagna e Repubblica federale tedesca, [in:]

A. Missiroli, G. Pasquino (eds.), Opposizione, governo ombra, alternativa, Roma-Bari 1990, pp. 119-120; G. Rizzoni, Oposizione..., p. 95.

27 G. Tsebelis, Decision Making in Political Systems: Veto Players in Presidentialism, Parliamentarism, Multicameralism and Multipartyism, «British Journal of Political Science» 1995, vol. 25, No. 3, p. 292.

28 Ibidem, p. 302. 
of interest groups putting forward heterogenic demands etc. The theory of veto points and 'playing with veto' supplements the methodology of the analysis of democratic systems by Robert Dahl ${ }^{29}$. It allows you to assess whether we are dealing with full polyarchy or façade democracy. It also allows for the inclusion of the concept of demarchy as a proposal of the connection of two principal political systems and mental currents, i.e. democracy and liberalism ${ }^{30}$. It also creates tools serving the purpose of assessing government systems in electoral democracy. The presumption is that the government majority acts in accordance with social expectations, and that free and fully democratic elections are only an instrument of democracy, and not its synonym ${ }^{31}$, in compliance with the assumption that the citizens' participation in the democratic process regards their influence on the shape of politics. Only in this way is the democratic process regards their influence on the shape of politics. Only in this way is the government system approaching civic preferences.

\section{Veto Points and Veto Players}

The victory of Andrzej Duda in the presidential elections of 2015 paved the way for the victory of PiS (Law and Justice) in the parliamentary election in October of the same year. The voters negatively assessed the period of the rule of Platforma Obywatelska (PO - Civic Platform) and Polskie Stronnictwo Ludowe (PSL - Polish People's Party) in the years 2007-2015. The activity of three cabinets of the liberal-centrist coalition of PO-PSL was accompanied by a decrease in the quality of law, quality of governance and quality of life in society ${ }^{32}$. The electoral success of PiS in 2015 announced a 'good change', meaning a departure from the so-called system of the Third Republic of Poland ${ }^{33}$. The centre-right assumed responsibility for the modernization of the system understood as the, "process breaking up the old solutions and creating

29 R. Dahl, Demokracja i jej krytycy, transl. Stefan Amsterdamski, Kraków 1995, pp. 117 ff.; R. Dahl, O demokracji, transl. Marcin Król, Kraków 2002, pp. 39, 81-82.

30 J. Szymanek, Dyspersja władzy: między jednolitościa a podziałem władzy, [in:] B. Szmulik, J. Szymanek (eds.), Interpretacje..., p. 224.

31 G.B. Powell, Jr., Wybory jako narzędzie demokracji. Koncepcje więhszościowe i proporcjonalne, transl. Marek Czekański, Warszawa 2006, p. 176.

32 A. Zybertowicz, M. Gurtowski, R. Sojak, Państwo Platformy. Bilans zamknięcia, Warszawa 2015, p. 109.

33 Cf. Z. Krasnodębski, Już nie przeszkadza, Kraków 2010, pp. 15 ff.; R. Matyja, Wyjście awaryjne. O zmianie wyobraźni politycznej, Kraków 2018, pp. 18 ff. 
new rules and new practice" 34 . This issue refers to the adequacy of institutions in the social context, because institutional changes (reforms) can be a response to social change or strive to create new desirable states in the sphere of the institutional system ${ }^{35}$. The opposition and the establishment of the Third Republic of Poland responded with a veto game in order to block the government mechanism. Using the support of the private media, it made attempts to incapacitate the actors of the public debate by making it impossible to refer to the "reasons and arguments" and vetoing all actions of the government majority in the parliament ${ }^{36}$. According to Tsebelis's concept, a veto player is each institutional entity able to effectively block the decision-making process ${ }^{37}$. The veto points are entities (structures) capable of creating mechanisms limiting, delaying and blocking the government's decisions, regardless of whether they are direct or indirect participants in the decision-making process. The direct participants in the game include, in particular, the President of the Republic of Poland, both houses of parliament, institution of the referendum, Constitutional Tribunal (TK) and the administration of justice. Indirectly, the public and private media take part in it as well as many other entities having international connections ${ }^{38}$. The basic playing fields of veto players include the parliament; relations between the parliament and the government; between parliament and the President and between the President and the government. The course of the game is influenced by the party establishment, pressure groups, heterogenic corporation and neo-corporation interests in addition to the advocates of 'supra-national' ideological visions of the third democratic revolution, who are difficult to relate to any specific political orientation or a concrete active and

34 R. Rydlewski, Modernizacja administracji. Studium polityk administracyjnych $w$ Polsce, Warszawa 2015 , p. 46. The uniqueness of the division onto the left-wing and right-wing in Poland regards the fact that anyone who questions the powers from Magdalenka, which prepared the 'Round Table' agreement, is included in the conventional right-wing (even if the person is the most confident socialist and statist). On the other hand, initially, those who fell withing the left-wing were the ones who were connected with the opinion-forming circle inculcating a caricatured vision of Polish history and making patriotism and catholicism uglier, which was done for the sake of the Polishness project that was to be modern, enlighted, and 'European' - whatever that means.

35 Constancy of unfit and inefficient institutions might generate dysfunctions, conflicts and social dissatisfaction. I. Bokszczanin, Hybrydyzacja demokracji lokalnej w państwach Europy Południowej (Francja, Hiszpania, Wtochy), Warszawa 2019, p. 42.

36 P. Gliński, Niszczenie sfery publicznej, https://wpolityce.pl/polityka (23.11.2019).

37 According to Tsebelis, they include the players whose protest cannot be rejected. Idem., Veto Players: How Political Institutions Work, New Jersey 2002, p. 19.

38 K. Decko, Skuteczność Unii Europejskiej w negocjacjach a gracze weto, «Wrocławskie Studia Politologiczne» 2014, No. 16, p. 128. 
relevant party on the domestic political scene. The possibility of a compromise between the players depends on the scale of polarization on the political scene, which is determined by the ideological distance between the players ${ }^{39}$. The profit and loss account determines success, but it is not a zero-sum game. It depends on the mechanisms of the state's political and government system defined in the Basic law. The Constitution of the Republic of Poland from 1997 was constructed in such a way as to avoid disputes and tensions within the relations between particular organs of authority. This has been recently confirmed by the controversy pertaining to the state's representation in the summits of the European Council in 2009, and the dispute from autumn 2015 generated by the new act on the Constitutional Tribunal from 25 June 2015. It should be honestly stated that there are many potentially controversial situations since, out of necessity, the Basic law regulates only a selected fragment of the reality of the system of government. It is not able to foresee all possible future events which might become the grounds for controversies. As it was already mentioned above, the system of government in the Republic of Poland is based on the principles of separation and balance of powers: legislative, executive and judicial. The representatives of the doctrine indicate that it is not fully known whether it results in the primacy of the separation of power, its balancing or maybe an order regarding the cooperation of the divided authorities ${ }^{40}$. Judicial power - in accordance with art. 10 item 2 in fine of the Constitution of the Republic of Poland - is vested in the courts and tribunals.

\section{A game between authorities}

In accordance with the provisions of art. 122 of the Constitution, the signature of the President of the Republic of Poland is the condition for an act to be enacted ${ }^{41}$. However, some situations might occur when the President has doubts as to the correctness (purposefulness) of the solutions adopted in the act or the compatibility of the act with the constitution. Then he/she can refuse to sign the act and within 21 days

39 G. Sani, La polarizzazione rivisitata, [in:] G. Pasquino (ed.), La scienza politica di Giovanni Sartori, Bologna 2005, p. 156; O. Höffe, La democrazia nell'era della globalizzazione, Bologna 2007, p. 319.

40 B. Szmulik, J. Szymanek, Podziat wtadzy jako zasada prawa konstytucyjnego, [in:] B. Szmulik, J. Szymanek (eds.), Interpretacje..., p. 88.

41 Prezydent wobec uchwalonych ustaw, https://www.prezydent.pl (18.11.2019). 
pass it to the Sejm with a justified motion to have the act reexamined. This motion is called a 'veto'. If the President vetoes an act, the final decision concerning the nature of the act belongs to the Sejm, which can reject the president's opinion (so long as it passes the act again with a qualified majority of $3 / 5$ of votes in the presence of at least half of the statutory number of deputies). In July 2017, President A. Duda vetoed the amendment to the Act on regional accounting chambers. Also, in July 2017, the President vetoed the Act on the Supreme Court (SN) and an amendment to the Act on the National Council of the Judiciary of Poland (KRS), with him suggesting that it was partially unconstitutional. The President's motion to have the Act on the SN reexamined concerned the draft bill passed on $20 \mathrm{July}, 2017^{42}$. None of the presidential vetoes were reexamined by the Sejm. The fact that the Sejm did not reject the presidential veto resulted in the closing of the legislative process. The regulations do not determine the date when the presidential veto should be examined. However, some representatives of the doctrine indicate that if the president directs his/her veto together with the reasons to the Sejm, the latter should examine it. It should be remembered that the Standing Orders of the Sejm do not impose on the Sejm the date when presidential motions to have the acts re-examined should be examined. During the term in office of 2015-2020, president A. Duda signed 1066 legal acts in total and vetoed 9. He submitted 32 legislative initiatives in the Sejm, the most important of which was, i.a., the Act on Solidarity Supplement which is awarded in order to counteract negative effects of COVID-19 or the amendment of the Family code. From the perspective of the whole term in office (June 2020) and foreign policy, A. Duda's presidency was active. It involved 109 official visits abroad, 166 foreign delegation visits in Poland, 78 international memorandums of understanding, 370 ratified and announced international agreements. In the field of defence, its main priorities included the permanency of the presence of NATO troops in Poland, the reform of the command and control system of the Armed Forces of the Republic of Poland and the establishment of the Territorial Defence Force. Within the scope of social policy, it concerned actions supporting Polish families and retirees, an increase in the minimum wage and a series of pro-civic initiatives. The President was active in operations pertaining to health protection aiming at the development of a National Oncology Strategy (Narodowa Strategia Onkologiczna), the establish-

42 After that date the Parliament passed a new Act on the SN - 8 December 2017. It was signed by the President of the Republic of Poland and has been in force since 3 April 2018. The Act on the KRS has already been amended, too. 
ment of a special Medical Fund (Fundusz Medyczny) and "Leki 75+" ("Medicine $75+$ ") programme of free medicine for persons who attained 75 years of age. The relationship between President A. Duda with the PiS leader Jarosław Kaczyński were changeable. Its culmination was in the presidential veto of Acts whose aim was to reform the administration of justice $^{43}$. In response, Senators belonging to PiS blocked the project that was crucial for the President to conduct a constitutional referendum that was to take place on 10-11 November 2018 during which voters were to answer questions: whether they are in favour of amending the binding Constitution of the Republic of Poland adopted on 2 April 1997 or should the Basic law remain unaltered.

It has already been mentioned that after 1989, judges as a corporation constituted an important element of the oligarchy of the Third Republic of Poland. According to the anchoring theory, it was to be expected that after the 2015 elections, they would seek to transform the administration of justice into another veto point. Active participation in the public debate after 2015 of many judges of the SN, the KRS, the TK and the Commissioner for Human Rights (RPO) was leading to the blurring of differentiation between "governance through law" and "the rule of law" 44 This led to justitocracy ${ }^{45}$, while the administration of justice, by definition, was to protect the establishment of the Third Republic of Poland from the rule of the "unenlightened mob" 46 . The analysis of relations between legislation, the executive branch and the administration of justice after 2015 confirms the thesis that the traditional standpoint of liberal constitutionalists towards the judicial control of the acts of law was unconvincing, and in some respects courts were not more rational than the legislature ${ }^{47}$. When the parliament adopted the acts on courts, the former president of the TK, Andrzej Rzepliński, said that judges should defend the autonomy of the judiciary, "even if they were to be led out in cuffs" 48 . The government majority decided that in accordance with art. 187 of the Constitution, the reform of the KRS should be continued. The next step was the reform of the SN. Parliamentary opposition was supported

43 As a consequence of the Presidential veto the task of reforming the administration of justice was moved to the next, 9th term-of-office of the Sejm.

44 R. Barros, Dyktatura i rzady prawa: normy prawne i władza wojskowa $w$ Chile Pinocheta, [in:] J.M. Maravall, A. Przeworski (eds.), Demokracja i rzady prawa, transl. Paweł Kazimierczak, Jan Winczorek, Warszawa 2010, pp. 185 ff.

45 J. Zaleśny, Kontrola..., pp. 182-183.

46 W. Sadurski, Dyktatura ignorancji, «Newsweek» 2017, No. 27.

47 I. Shapiro, Stan..., p. 86.

48 I śmieszno i straszno, https://wpolityce.pl/polityka (01.05.2018). 
by the Venice Commission ${ }^{49}$. Prejudicial questions went to the Court of Justice of the European Union (CJEU). The government argued that referring to indefinite rules of lawfulness was unjustified and the matter of the administration of justice was not within the range of the European Union law. The representatives of the government indicated that the proposed solutions within the frames of the reform of the administration of justice did not principally differ from those that function in the states of the 'old Union'. The European Commission (EC) announced on 10 October 2019 that they had referred Poland to the Court of Justice, "to protect judges from political control" 50 . The reason was that the new system of disciplinary measures did not ensure independence and impartiality of the Disciplinary Chamber of the Supreme Court, which is composed solely of judges selected by the National Council for the Judiciary, which is itself politically appointed by the Sejm ${ }^{51}$. It appeared that the Polish judges were losing independence and impartiality only because their appointment was made by the judges mainly appointed from among the judges by politicians. The act of political nomination itself by its very nature means corruption, but only in the case of Poland. The German penal code provides for the possibility of punishing the judges for the activities that distort the course of the administration of justice ${ }^{52}$. In France, organized activities which seek to make the work of the judiciary impossible or difficult are prohibited ${ }^{53}$. Similar solutions in Poland are blocked by the European Commission. Why does it happen? Similar accusations are put forward against Hungary ${ }^{54}$, which is also governed by the Right that - according to the adopted logic - does

49 The Venice Commission, meaning the European Commission for Democracy through Law, examined the state of the rule of law in Poland in connection with the amendment of the acts on courts. The first meeting concerning the danger to democracy and the rule of law in Poland was organized and financed by one of the concerns running a chain of hypermarkets in Poland. It took place as early as just after the 2015 elections. Prof. Krasnodębski ostrzega, https://wpolityce.pl/polityka (6.12.2019).

50 Skarga Komisji Europejskiej przeciwko Polsce trafita do TSUE, https://www.polsatnews.pl (29.10.2019).

51 Similar activities are undertaken by the European Commission against Hungary referring to art. 7 of the EU Treaty. Wegry przed Komisja Europejska, https://wpolityce.pl/swiat/477005wegry-przed-ke-varga-to-polityczne-polowanie-na-czarownice (10.12.2019).

52 https://www.iustitia.pl/postepowania-dyscyplinarne/3475-komentarz-neue-richtervereinigung-nrv-dotyczacy-przestepstwa-z-art-339-niemieckiego-kodeksu-karnego (24.06.2020).

53 https://www.zachod.pl/158209/francuscy-sedziowie-podlegaja-sankcjom-choc-sa-one-bardzorzadkie/ (24.06.2020).

54 L. Békési, Negative Discrimination and its Problems Arising in Labour Law Relationships in the European Union and Hungarian Legal Regulations, «Comparative Law Review» 2017, No. 23, pp. $111 \mathrm{ff}$. 
not have the same rights as the Left. All members of the European Commission were chosen in a political way and they are nominated by the governments of the EU states. It is they who demand the right to lodge a complaint against Poland as if the European Union was an 'independent' public prosecutor although its members are the political representatives of mostly Leftist governments. If we adopted the line of thinking according to which each political nomination makes impartiality and independence impossible 55 , first of all the European administrations of justice should be accused. The whole concept by virtue of which the election of judges to the KRS by the parliamentary (qualified) majority proved illogical, which in part is confirmed by the decision of the CJEU in the case concerning the regulations referring to the Disciplinary Chamber of the $\mathrm{SN}^{56}$. The European Court has accepted that the issue of the independence of judges and the independence of courts is essentially a constitutional matter, outside the area of competences conferred on EU bodies, and has refrained from answering whether the National Court Register and the Disciplinary Chamber of the Supreme Court are properly appointed. It stated that, in reference to the very circumstances in which the appointment of the Disciplinary Chamber members took place: "first it should be made precise that the very fact they are called by the President of the Republic of Poland cannot cause those members to be dependent on this organ or arouse any doubts as to their impartiality if after the appointment those persons are not subject to any pressure and they do not get any recommendations while doing their duties" 57 . Therefore, the Tribunal acknowledged that it was the SN which had to decide if the Disciplinary Chamber was so independent that it could settle disputes on the judges' retirement. The decision of the CJEU from 19 November confirms that contemporary liberal democracies suffer from a kind of hypertrophy of the judicial authority ${ }^{58}$. It is the judges

55 A section of judges decided to make decisions on who is a legal judge, although every judge sworn on an oath to the President becomes one as this very act means using the personal prerogative provided by art. 179 of the Constitution.

56 The establishment of the Disciplinary Chamber within the structure of the SN was treated by the judges' circles with great dissatisfaction. „Kasta” wzywa do sabotazu, https://wpolityce. pl/polityka/476916-rzecznik-sn-nie-stawilbym-sie-przed-izba-dyscyplinarna (10.12.2019).

57 Trybunał Sprawiedliwości Unii Europejskiej, Komunikat Prasowy nr 145/19, Luksemburg, 19 listopada 2019, https://curia.europa.eu/jcms/upload/docs/application/pdf/2019-11/ cp190145pl.pdf, p. 2.

58 As a reaction to the ruling by the CJEU from 19 November, 2019 the judges of the Constitutional Tribunal directed a letter to the President of the Republic of Poland where they demanded that representatives of the legislative and the executive powers pass a new act on the KRS. The new act should guarantee a way of appointing 15 judges - members of the 
who make free and arbitrary interpretations and changes in legislation and perform the function which Montesquieu did not anticipate ${ }^{59}$. The system where judges appointed by judges can discipline judges reminds one of a caste system ${ }^{60}$. The shaken trust of the citizens in the reliability and impartiality of judicial procedures and in the ethical standards of law corporations ${ }^{61}$, is, in the opinion of the President of the Republic of Poland, a potential source of pathologies and threats to the public order.

\section{The institutionalization, status of the opposition, dialogue between the government and opposition}

In many electoral democracies, the post-election validated representation of the majority of citizen depends on the degree of actual participation in the shaping of the national policy by political parties participating in the government. According to the proportion of participation in the legislature and the likely negotiating effectiveness, each party present in the parliament, including the opposition, can influence the government's policy by controlling and correcting government actions and by presenting alternative program propositions. The proportion of influence of the governing parties and opposition parties is indicated by the distance on the leftisim - rightism scale ${ }^{62}$. The status of the opposition is determined by the rules and regulations of the Sejm and the Senate as the basis for active participation in establishing all the internal organs of the parliament. Even a few candidates for the Sejm Marshal (Speaker) can be submitted on the initiative of the opposition. Opposition groups

KRS - which will be consistent with the system, historical and functional interpretation of art. 187 of the Constitution and which will make the judges want to satisfy the requirements of independence and impartiality as well as justice as provided in art. 45 of the Constitution. Byli sędziowie TK pisza do prezydenta, https://dorzeczy.pl/obserwator-mediow/121915/ byli-sedziowie-tk-pisza-do-prezydenta (29.11.2019).

59 He wrote: "If the executive power does not have the right to check the enterprises of the legislative body, the latter will be despotic, for it will wipe out all the other powers". Monteskiusz, $O$ duchu..., p. 153.

60 While assessing the decade after the fall of communism in the countries of Central and Eastern Europe, Piotr Wandycz notes that the legal system in Poland "continues to bear certain hallmarks of the previous epoch”. P. Wandycz, Cena wolności. Historia Europy Środkowowschodniej od średniowiecza do wspótczesności, transl. T. Wyrozumski, Kraków 2003, p. 410.

61 List Prezydenta RP do uczestników i organizatorów Kongresu Prawników Polskich, https://wyborcza.pl/7,75398,21838912,list-prezydenta-andrzeja-dudy-do-uczestnikow-i-organizatorow.html (01.12.2019).

62 G.B. Powell, Wybory..., pp. 116, 193. 
have the right to participate in the formation of the Sejm Presidium which must include - apart from the already elected Marshal - deputy Marshals. The Presidium of the Sejm should always reflect the existing system of political powers in the House, but in practice some possibilities of discrimination against the opposition groups cannot be excluded. A lot depends on the number of parliamentary clubs and groups ${ }^{63}$. Contrary to the Presidium of the Sejm, where in practice the possibility of limiting the pluralist character of this organ cannot be excluded, the opposition has the guaranteed right in the rules and regulations to represent and participate in the realization of the function of the Council of Elders. In accordance with art. 15 item 1 of the Standing Orders of the Sejm of the Republic of Poland, this refers to, "parliamentary clubs if they represent at least 15 Deputies, as well as the representatives of parliamentary groups which on the day of the beginning of the term of office of the Sejm represented a separate list of candidates" 64 . The binding regulations of the Standing Orders and the well-established customs of the Sejm guarantee the participation of the opposition in the shaping of the personal composition of standing and special committees as well as subcommittees. The principle of proportionality also concerns the participation of the opposition in committees of inquiry. These solutions are binding for all internal organs of the Sejm, which creates a guarantee for the opposition to exert definite influence on the course of parliamentary work. Without a doubt, the most favourable situation for the parliamentary opposition is the one when particular decisions can only be made by a qualified majority during the meetings of the Sejm. This is the case, for example, when a constitutional act is passed. Apart from the provisions of the constitution, a qualified majority is also required by the Standing Orders of the Sejm for decisions on the consent to hold a deputy liable for the committed offences ${ }^{65}$. Of key importance for the efficiency of the political system in a democratic system of government is the participation of the parliamentary opposition in the legislative function of the Sejm. In this case, a controlling and corrective role of the opposition is revealed that constitutes an integral part of the decisionmaking process in parliament, as well as on the level of relations between parliament and government. The novelty in the government - opposition

\footnotetext{
63 A considerable success of the opposition after parliamentary elections in 2019 was the fact that the opposition had a candidate of the Left for the chairperson of the Sejm commission of the social policy and family affairs committee.

64 http://biuletyn.mon.gov.pl/pliki/File/Lobbing/RegulaminSejmu.pdf (01.12.2019).

65 S. Bożyk, Opozycja..., p. 83.
} 
relations after the elections in 2015 was the emergence of the non-parliamentary opposition. It was the so called Committee for the Defense of Democracy (Komitet Obrony Demokracji) led by Mateusz Kijowski who was joined by the Citizens of Poland (Obywatele RP) led by Paweł Kasprzak and other ad hoc groups. They operated in agreement with the parliamentary opposition after the failure of the strategy of dissolving the parliament proceedings, disrupting the proceedings of the parliament from taking place according to the regulations, or making it impossible to take any decisions, meaning everything in the doctrine is termed as parliamentary obstruction. Opposition mobilised their supporters outside the building of the Sejm in order to take to the streets the crowds that were frightened of the possibility of "being thrown out from the Union”, or at least, having the amounts from the Union funds reduced ("street opposition"). Parliamentary opposition stopped dealing with a policy and personnel alternative, which resulted from the style of political leadership ${ }^{66}$. It assumed that the only chance to overcome PiS was an agreement with the left and the presidents of big cities who decided to "get out of the control" of central authorities and backed the pragmatic and "operational" recognition of nonpartisanism ${ }^{67}$. A significant number of representatives of local (self-government) authorities decided in this situation to build an alternative state within the frames of local communities ${ }^{68}$. The Coalition of Citizens (Koalicja Obywatelska - KO), established before the local government elections in 2018, consisting of the Civic Platform (Platforma Obywatelska, PO), Modern (Nowoczesna), Polish Initiative (Inicjatywa Polska) and Green Party (Zieloni), recognised the state of democracy in Poland as fatal as a consequence of violating the principles of 'law, including the constitution, and building

66 The political styles of both PO leaders, namely Grzegorz Schetyna, and earlier Donald Tusk, were imposed authoritarianism. The reverse was the "political style" of the PiS leader directed at achieving consensus around the designed changes. Cf. J. Richardson, G. Gustaffson, G. Jordan, The Concept of Policy Style, [in:] J. Richardson, G. Gustaffson, G. Jordan (eds.), Policy Styles in Western Europe, Allen \& Unwin, London 1982, pp. 2-9; P. Żukiewicz, Przywództwo polityczne. Teoria i praktyka, Warszawa 2011, pp. $46 \mathrm{ff}$.

67 A. Gendźwiłł, Bezpartyjni prezydenci miast $i$ ich znaczenie dla lokalnej polityki, «Studia Regionalne i Lokalne» 2010, No. 2 (40), p. 103.

68 The Presidents of the big cities argue that they had to put the load of changes on their shoulders if the government undermines the foundations of liberal democracy. They entered the sphere of international relations. In December 2019 a meeting of the mayors of the capital of Slovakia, the Czech Republic, Hungary and Poland took place in Budapest because - in their opinion - politicians did not undertake any effective activities related to the climate crisis. https://wpolityce.pl/polityka/477852-trzaskowski-zapowiada-podpisanie-paktuwolnych-miast (16.12.2019). 
a party state'69. $\mathrm{KO}$ combined the social democratic tradition with the ideas of neo-liberal thought by implementing the concept of a 'hybrid state $^{\prime 70}$. It had huge support from liberal-leftist private media (press, radio, television, internet portals), delighted with the establishment of a resistance movement against the "authoritarian state" 71 . The extremely politicised Judges' Association 'Iustitia' promoted digital subscription of 'Gazeta Wyborcza' that unilaterally presents only one side of the political and ideological dispute. The government majority recognised that the servient role of the state is an alternative to "late post-communism" strengthened until 2015, when the executive power had actual control "over all stronger media"72. Pursuant to the diagnosis PiS, PO and PSL lost power but they still had a significant advantage in most media as they controlled "the mechanism of public opinion concentration" 73 . The opposition realized the plan of "street and abroad" which was to overthrow the legitimate government ${ }^{74}$. This eliminated any possibility of dialogue between the government and the opposition.

\section{The political scene after the parliamentary elections of 2019 in reference to the asymmetric bicameralism}

It can be argued that for a democracy to rule in a state, at least one condition has to be satisfied, which is the existence of a clear criterion determining which of the political parties should hold power. The second condition is an attachment to the rule of law. One of the many theories on the rule of law assumes that there are situations when everybody abides by the law. An alternative theory anticipates that the emergence of the rule of law is a result of a conflict of interests. Both views lead to the conclusion that under certain conditions the actors on the political scene act in accordance with law, which can be explained by political culture. The effect is that "the political forces of the opposition observe

69 Twoja Polska. Program Koalicji Obywatelskiej, https://platforma.org/upload/document/86/ attachments/121/KO\%20Program.pdf, p. 9 (12.02.2019).

70 Gf. J. Loughlin, Reconfiguring the nation-state vs. uniformity, [in:] J. Loughlin, J. Kincaid, W. Swenden (eds.), Routledge Handbook of Regionalism $\&$ Federalism, London 2013, pp. 3 ff.

71 Prawda o polskich mediach, https://www.odkrywamyzakryte.com (23.12.2019); cf. W. Kieżun, Patologia transformacji, Warszawa 2012, pp. 158 ff.

72 Dobry czas dla Polski. Polski model państwa dobrobytu. Program Prawa i Sprawiedliwości 2019, Warszawa 2019, pp. 27, 32.

73 Ibidem, p. 36.

74 Ibidem, p. 38. 
the law in their own interest counting on all others doing the same"75. PiS did not wish to annihilate the opposition, and the leader of the party announced he was ready to establish an agreement with the opposition, which would "end the war on the Polish political scene"76. The political scenario for the future was to be determined by the results of parliamentary elections in 2019 (table 1).

Table 1. Results of political parties and committees in the 2019 elections to the Sejm of the Republic of Poland

\begin{tabular}{|c|c|c|c|c|}
\hline Electoral committee & $\begin{array}{l}\text { Number } \\
\text { of votes }\end{array}$ & Percentage & Mandates & $\begin{array}{l}\text { Percentage } \\
\text { of mandates }\end{array}$ \\
\hline $\begin{array}{l}\text { Prawo i Sprawiedliwość } \\
\text { (Law and Justice) }\end{array}$ & 8051955 & 43.95 & 235 & 51.09 \\
\hline $\begin{array}{l}\text { Koalicja Obywatelska (Coalition } \\
\text { of Citizens: PO, Niezależna, Zieloni) }\end{array}$ & 5060355 & 27.40 & 134 & 29.13 \\
\hline $\begin{array}{l}\text { Sojusz Lewicy Demokratycznej } \\
\text { (The Democratic Left Alliance) }\end{array}$ & 2319946 & 12.56 & 49 & 10.65 \\
\hline $\begin{array}{l}\text { Polskie Stronnictwo Ludowe } \\
\text { (The Polish People's Party) }\end{array}$ & 1578523 & 8.55 & 30 & 6.52 \\
\hline $\begin{array}{l}\text { Konfederacja Wolność } \\
\text { i Niepodległość (The Freedom } \\
\text { and Independence Confederation) }\end{array}$ & 1256953 & 6.81 & 11 & 2.39 \\
\hline $\begin{array}{l}\text { Koalicja Bezpartyjni Samorządowcy } \\
\text { (Nonpartisant Local Government } \\
\text { Activists) }\end{array}$ & 144773 & 0.78 & 0 & 0.00 \\
\hline $\begin{array}{l}\text { Mniejszość Niemiecka } \\
\text { (German Minority) }\end{array}$ & 32094 & 0.17 & 1 & 0.22 \\
\hline $\begin{array}{l}\text { Skuteczni Piotra Liroya-Marca } \\
\text { (The Effective) }\end{array}$ & 18918 & 0.10 & 0 & 0.00 \\
\hline $\begin{array}{l}\text { Akcja Zawiedzionych Emerytów } \\
\text { i Rencistów (Action of Disillusioned } \\
\text { Retirees) }\end{array}$ & 5448 & 0.03 & 0 & 0.00 \\
\hline Prawica (The Right) & 1765 & 0.01 & 0 & 0.00 \\
\hline
\end{tabular}

Source: https://wybory.gov.pl/sejmsenat2019/pl/wyniki/sejm/pl (18.02.2021).

75 A. Przeworski, Dlaczego partie polityczne respektują wyniki wyborów?, [in:] J.M. Maravall, A. Przeworski (eds.), Demokracja i rzady prawa, transl. Paweł Kazimierczak, Jan Winczorek, Warszawa 2010, p. 115.

76 Kaczyński zaproponowat opozycji „zakończenie wojny”, https://natemat.pl/278999,kaczynskiproponuje-opozycji-zakonczenie-wojny-wywiad-prezesa-pis-dla-pap (03.12.2019). 
For the first time since the democratic elections in 1991, the party which obtained the greatest number of seats in the Sejm did not have a majority in the Senate (table 2).

Table 2. Results of political parties and committees in the 2019 elections to the Senate of the Republic of Poland

\begin{tabular}{|l|c|c|c|c|}
\hline \multicolumn{1}{|c|}{ Electoral committee } & $\begin{array}{c}\text { Number } \\
\text { of votes }\end{array}$ & Percentage & Mandates & $\begin{array}{c}\text { Percentage } \\
\text { of mandates }\end{array}$ \\
\hline $\begin{array}{l}\text { Prawo i Sprawiedliwość } \\
\text { (Law and Justice) }\end{array}$ & 8110193 & 44.56 & 48 & 48.00 \\
\hline $\begin{array}{l}\text { Koalicja Obywatelska (Coalition } \\
\text { of Citizens: PO, Niezależna, Zieloni) }\end{array}$ & 6490306 & 35.66 & 43 & 43.00 \\
\hline $\begin{array}{l}\text { Polskie Stronnictwo Ludowe } \\
\text { (The Polish People's Party) }\end{array}$ & 1041909 & 5.72 & 3 & 3.00 \\
\hline $\begin{array}{l}\text { Sojusz Lewicy Demokratycznej } \\
\text { (The Democratic Left Alliance) }\end{array}$ & 415745 & 2.28 & 2 & 2.00 \\
\hline $\begin{array}{l}\text { Lidia Staroń - Zawsze Po Stronie } \\
\text { Ludzi (Always on People's Side) }\end{array}$ & 106035 & 0.58 & 1 & 1.00 \\
\hline $\begin{array}{l}\text { Komitet Krzysztofa Kwiatkowskiego } \\
\text { (Krzysztof Kwiatkowki's Committee) }\end{array}$ & 79348 & 0.44 & 1 & 1.00 \\
\hline $\begin{array}{l}\text { Komitet Wadima Tyszkiewicza } \\
\text { (Wadim Tyszkiewicz's Committee) }\end{array}$ & 63675 & 0.35 & 1 & 1.00 \\
\hline $\begin{array}{l}\text { Demokracja Obywatelska } \\
\text { (Civic Democracy) }\end{array}$ & 44956 & 0.35 & 1 & 2.00 \\
\hline
\end{tabular}

Source: https://wybory.gov.pl/sejmsenat2019/pl/wyniki/sejm/pl (18.02.2021).

The general conclusion after the 2019 elections is as follows: the possibility of breaking the traditional conflict based on the mutual dislike of the old post-communist elite and the people rejecting it emerged, which created tension so strong that it invalidated all substantive disputes between the parties to the political dispute. Simultaneously, the era of a duopoly based on the contrast PiS - PO was coming to an end. The co-existence of as many as five political parties in the Sejm has created an outline of a new division into the forces of the left, the center and the right after the parliamentary elections. PiS has taken the permanent role of a party of the center. However, in order to effectively govern it had to agree decisions with the party of Jarosław Gowin (Porozumienie - Agreement) and Zbigniew Ziobro (Solidarna Polska - United Poland), forming a centre-right coalition called United Right (ZP). Konfederacja 
group (national right-wing), had a choice: either cooperation and agreement with ZP or proud isolation (or, possibly getting close to PSL - the party which can govern "with everybody"). The opposition obtained the possibility in the Senate to block (delay) the legislative process initiated in the Sejm. This is promoted by an unclear formula of bicameralism, which was mentioned before. The position of the Senate in the system of government corresponding to the model of asymmetric bicameralism is regulated in the provisions of chapter IV of the Constitution. Art. 10 of the Constitution provides expresis verbis that legislative power is vested in the Sejm and the Senate. Therefore, certain doubts may arise as to the nature of participation of the second house in the legislative process if not for the constitutional sequence from art. 118 to art. 122. A clearly asymmetric picture of the Senate emerges as the, 'co-legislative' house. This was frequently emphasized by the TK in its opinions, which point to the role of the Sejm as the "host of each act"77. Formally, the Senate does not pass acts but only examines them. An imperfect model of relations between the Sejm and the Senate is also visible in the control function of the parliament. The Constitution makes a clear reservation that the realization of these tasks belongs exclusively to the Sejm (art. 95 item 2). The consequence is that the Senate is deprived of any control over the government. Following the announcement (the end of November 2019), the Senate started inhibiting the legislative initiatives of the government majority in the Sejm. The opposition constituting the majority in the Senate became important, as the Constitution of the Republic of Poland provides a possibility not only to the Sejm but also to the President of the Republic of Poland of calling a referendum with the consent of the Senate. The political plan of $\mathrm{PO}$ as the main opposition party regarded the strengthening of its fragile majority in the Senate, winning the presidential election in summer 2020, next reversing the political trend favouring PiS, and finally shortening the term of office of the Sejm.

Coming back to the election results. Place of residence had a significant impact on the preferences. In metropolises (above 500,000 inhabitants), KO secured a decisive victory over PiS - 41:27\%. Lewica achieved very good results by polling $19 \%$, while PSL had only $6 \%$. KO was also victorious against $\mathrm{PiS}$ in bigger cities with a population ranging between 200,000 to $500,000(39: 32 \%)$. In rural areas, PiS remains the leader with

77 O. Kazalska, Domniemanie przyjęcia poprawki senackiej jako konstytucyjny standard procesu legislacyjnego, «Przegląd Europejski» 2019, No. 1, pp. 76 ff. 
the support of $56 \%$. KO obtained only $17 \%$, Lewica $-7.5 \%$, and PSL got quite good results $-12 \%$. The results for towns with a population of up to 50,000 resemble those of all Poland, whereas in medium-sized cities (from 50,000 to 200,000) the advantage of PiS over KO was only $38: 32 \%$. PiS won in 15 out of 16 voivodships. The last PO fortress was the Pomeranian voivodship. The results in terms of particular age groups are interesting, and they give us a lot to think about. PiS won in each of these groups, having the greatest support in the group aged 60 and above - as many as $55.6 \%$ of votes. In the same group, $\mathrm{KO}$ obtained $25.3 \%$ support, SLD - 10\%, PSL - 7.4\%, while Konfederacja 1.1\% Among the youngest voters, that is individuals between 18 and 29 years of age (chart 1) - PiS obtained 26.2\% support, KO - 24\%, Konfederacja - 20.2\%, SLD - 17.7\%, and PSL - 10.3\%.

\section{Chart 1. Young people's (18-29-year-olds) votes (in \%)}

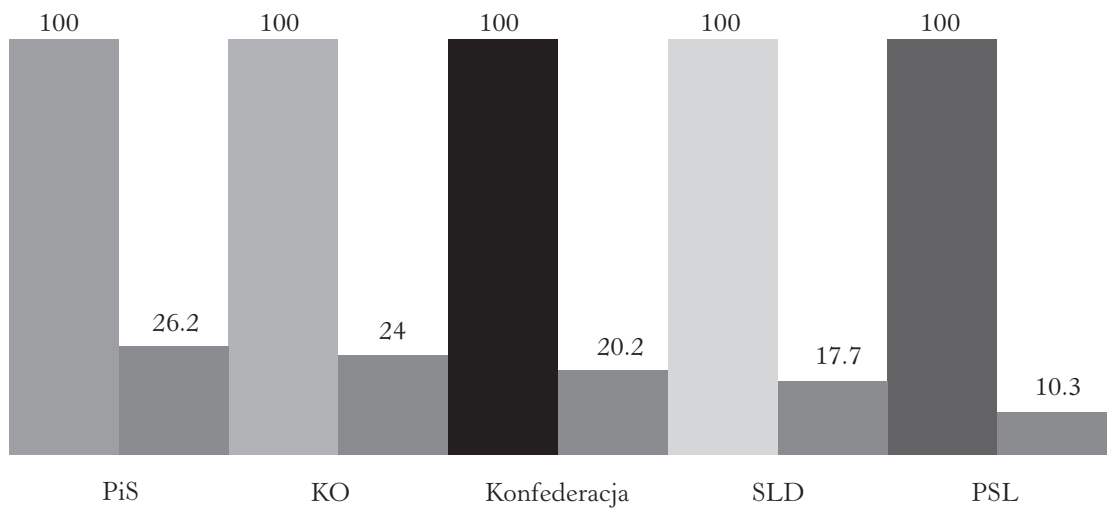

Source: https://www.polityka.pl/tygodnikpolityka/kraj/1928140,1,jak-glosowali-mlodzi-i-starsimiasto-i-wies.read (04.12.2019).

The breakdown of the results in particular professional groups is equally interesting. Two thirds of farmers supported PiS (67.4\%) and a good result was achieved by PSL - 17.1\%. In this group $\mathrm{KO}$ achieved $7.8 \%$, SLD - 3.5\%, while Konfederacja 3.4\%. Company owners or coowners were most willing to vote for $\mathrm{KO}$, which was supported by $38.8 \%$ of the above-mentioned, PiS - 29.5\%, SLD - 12.1\%, PSL - 9.9\%, and Konfederacja - 8.8\%. The pre-presidential campaign in June 2020 confirmed that, despite intellectual ambitions of leaders, the opposition is shallow, superficial, and based on stereotypes in terms of its programme and that they count on gaining an advantage in the "clash of civilisations" 
type of confrontation ${ }^{78}$. Voters were subjected to an attempt of changing reality to its distorted, virtual image in which emotions artificially created by administrators of huge global media rule. Similarly, to parliamentary elections (2019), the presidential elections (2020) regarded the protection of the traditionally understood verifiability of politics, in accordance with the Latin proverb: "Tantum intende in republica, quantum tuts civibus probavi possis". The government majority supporting the incumbent president not only intended to but could also convince citizens. The opposition resigned from a programme alternative in favour of an ideological dispute and the protection of the so called European values. After the withdrawal of the extremely unsuccessful nomination of Małgorzata Kidawa-Błońska by PO, a chance was given to Rafał Trzaskowski. The voters were choosing between ideological radicalism hidden under the slogans of tolerance and taking into account reality.

\section{Conclusion}

It is indicated, with some justification, that the differentiation in the parliamentary system between the executive power and the legislative power does not make practical sense as the government (executive power) is the emanation of the parliamentary majority (legislative power), and the traditional divisions were substituted by a crucial division for the state that regards the power of the government and the opposition. The hypothesis of de-democratization in Poland after the 2015 elections, suggesting that the process of democratic changes in Poland is in retreat, is not confirmed by the evidence presented in this article. Elections take place regularly, without any restrictions such as those concerning gatherings and the media or the de-legitimization of the opposition, while the latter tries to undermine the legally established government majority by negating the acts adopted by the Sejm and by questioning in courts the decisions taken by the organs of administration. The activities of the opposition are supported by the private media and certain corporations. They are based on the reference to political liberalism understood as limiting the role of the state and emphasizing individual freedom. The opposition is concentrated on an ideological message. Despite intellectual ambitions, its programme proposal is based on stereotypes and the

78 A. Nowak, Te wybory to starcie cywilizacji, talking: Maciej Pieczyński, «Do Rzeczy» 2020, No. 25 (378). 
superficial. The centre-right parliamentary majority governing after 2015 is not undermining the democratic system. It does not come forward with any conflicting postulate therewith. The government does not suppress pluralism in the media; it does not control all aspects of governing the state; it is subject to constitutional limitations. Public institutions were not colonized by the political authority. They are not dismantled but under the process of reform. One cannot say that Poland is a country governed by the rightist populists where manipulated and cheated people are unaware of the content of political decisions. The government can count on the support of the county's citizens, which seem more significant than that enjoyed by the former party groups (PO-PSL).

\section{Bibliography}

Antoszewski A., Metodologiczne aspekty badań nad systemami rzadzenia, [in:] J. Szymanek (ed.), System rządów w perspektywie porównawczej, Warszawa 2014.

Antoszewski A., System polityczny RP, Warszawa 2012.

Barros R., Dyktatura i rzady prawa: normy prawne i władza wojskowa w Chile Pinocheta, [in:] J.M. Maravall, A. Przeworski (eds.), Demokracja i rzady prawa, transl. Paweł Kazimierczak, Jan Winczorek, Warszawa 2010.

Békési L., Negative Discrimination and its Problems Arising in Labour Law Relationships in the European Union and Hungarian Legal Regulations, «Comparative Law Review» 2017, No. 23.

Bokszczanin I., Hybrydyzacja demokracji lokalnej w państwach Europy Południowej (Francja, Hiszpania, Wtochy), Warszawa 2019.

Bożyk S., Opozycja parlamentarna w Sejmie RP, Warszawa 2005.

Burda A., Doktryna konstytucyjna Monteskiusza, [in:] J. Bardach, K. Grzybowski (eds.), Monteskiusz i jego dzieto, Wrocław 1956.

Chorążewska A., Model prezydentury $w$ praktyce politycznej po wejściu $w$ życie Konstytucji RP $z 1997$ r., Warszawa 2008.

Dahl R., O demokracji, transl. Marcin Król, Kraków 2002.

Dahl R., Demokracja i jej krytycy, transl. Stefan Amsterdamski, Kraków 1995.

Dahl R. (ed.), Political Oppositions in Western Democracies, New Haven-London 1966.

Decko K., Skuteczność Unii Europejskiej w negocjacjach a gracze weto, «Wrocławskie Studia Politologiczne» 2014, No. 16.

De Mattei R., Dyktatura relatywizmu, transl. Piotr Toboła-Pertkiewicz, Emilia Turlińska, Warszawa 2009.

Fukuyama F., Tożsamość. Wspótczesna polityka tożsamościowa i walka o uznanie, transl. Jan Pyka, Poznań 2019.

Gendźwiłł A., Bezpartyjni prezydenci miast $i$ ich znaczenie dla lokalnej polityki, «Studia Regionalne i Lokalne» 2010, No. 2 (40).

Grzybowski M., Prezydencki arbitraż polityczny: uwarunkowania wyborcze $i$ ustrojowe, [in:] B. Szmulik, J. Szymanek (eds.), Interpretacje i reinterpretacje podziatu władzy, Warszawa 2020.

Held D., Modele demokracji, transl. Wojciech Nowicki, Kraków 2010. 
Höffe O., La democrazia nell'era della globalizzazione, Bologna 2007.

Kazalska O., Domniemanie przyjęcia poprawki senackiej jako konstytucyjny standard procesu legislacyjnego, «Przegląd Europejski» 2019, No. 1.

Kieżun W., Patologia transformacji, Warszawa 2012.

Krasnodębski Z., Już nie przeszkadza, Kraków 2010.

Levitsky S., Way L., The Myth of Democratic Recesion, «Journal of Democracy» 2015, vol. 26, No. 1.

Loughlin J., Reconfiguring the nation-state vs. uniformity, [in:] J. Loughlin, J. Kincaid, W. Swenden (eds.), Routledge Handbook of Regionalism \& Federalism, London 2013.

Machelski Z., Opozycja polityczna w Europie. Ujęcie porównawcze, Warszawa 2016.

Mastropaolo A., Verzichelli L., Il parlamento. Le assemblee legislative nelle democrazie contemporanee, Roma-Bari 2006.

Matyja R., Wyjście awaryjne. O zmianie wyobraźni politycznej, Kraków 2018.

Missiroli A., I «governi» dell'opposizione: Gran Bretagna e Repubblica federale tedesca, [in:] A. Missiroli, G. Pasquino (eds.), Opposizione, governo ombra, alternativa, Roma-Bari 1990.

Mouffe Ch., Per un populismo di sinistra, Bari-Roma 2018.

Nowak L., Podziat władzy w historii myśli politycznej - wybrane problemy, [in:] B. Szmulik, J. Szymanek (eds.), Interpretacje i reinterpretacje podziatu wtadzy, Warszawa 2020.

Pałecki K., Opozycja polityczna - próba typologii, [in:] K. Łabędź (ed.), Rola opozycji w systemach demokratycznych, Kraków 2016.

Pinelli C., Cambiamento o razionalizzazione della forma di governo, [in:] M. Volpi (ed.), Istituzioni e sistema politico in Italia: bilancio di un ventennio, Bologna 2015.

Pitruzzella G., Forme di governo e trasformazioni della politica, Roma-Bari 1996.

Powell G.B., Jr, Wybory jako narzędzie demokracji. Koncepcje większościowe i proporcjonalne, transl. Marek Cizekański, Warszawa 2006.

Przeworski A., Dlaczego partie polityczne respektuja wyniki wyborów?, [in:] J.M. Maravall, A. Przeworski (eds.), Demokracja i rzady prawa, transl. Paweł Kazimierczak, Jan Winczorek, Warszawa 2010.

Rizzoni G., Oposizione parlamentare e democrazia deliberativa. Ordinamenti europei a confronto, Bologna 2012.

Ruszkowski J., Ponadnarodowość w systemie politycznym Unii Europejskiej, Warszawa 2010.

Rydlewski R., Modernizacja administracji. Studium polityk administracyjnych $w$ Polsce, Warszawa 2015.

Sani G., La polarizzazione rivisitata, [in:] G. Pasquino (ed.), La scienza politica di Giovanni Sartori, Bologna 2005.

Schumpeter J.A., Kapitalizm, socjalizm, demokracja, transl. Michał Rusiński, Warszawa 2009.

Shapiro I., Stan teorii demokracji, transl. Izabela Kisilowska, Warszawa 2006.

Szmulik B., Szymanek J., Podział władzy: interpretacje i reinterpretacje, [in:] B. Szmulik, J. Szymanek (eds.), Interpretacje i reinterpretacje podziatu wtadzy, Warszawa 2020.

Szmulik B., Szymanek J., Podziat władzy jako zasada prawa konstytucyjnego, [in:] B. Szmulik, J. Szymanek (eds.), Interpretacje i reinterpretacje podziatu wtadzy, Warszawa 2020.

Szymanek J., Dyspersja władzy: między jednolitościa a podziałem władzy, [in:] B. Szmulik, J. Szymanek (eds.), Interpretacje i reinterpretacje podziału wtadzy, Warszawa 2020.

Szymanek J., Mechanizm racjonalizacji parlamentarnego systemu rząów: przegląd koncepcji, [in:] J. Szymanek (ed.), System rząów w perspektywie porównawczej, Warszawa 2014.

Tilly Ch., Demokracja, transl. Michał Szczubiałka, Warszawa 2008.

Tsebelis G., Veto Players: How Political Institutions Work, New Jersey 2002. 
Tsebelis G., Decision Making in Political Systems: Veto Players in Presidentialism, Parliamentarism, Multicameralism and Multipartyism, «British Journal of Political Science» 1995, vol. 25, No. 3 .

Wandycz P.S., Cena wolności. Historia Europy Środkowowschodniej od średniowiecza do wspótczesności, transl. T. Wyrozumski, Kraków 2003.

Witkowski Z., Woźniak W., Remarks on the contents of the power of pardon in the light, [in:] Z. Witkowski, J. Jirásek, K. Skotnicki, M. Serowaniec (eds.), Wspótczesne problemy sadownictwa $w$ Republice Czeskiej i w Rzeczypospolitej Polskiej, Torun 2017.

Zaleśny J., Kontrola konstytucyjności prawa: nowa aranżacja podziału władzy, [in:] B. Szmulik, J. Szymanek (red.), Interpretacje i reinterpretacje podziału władzy, Warszawa 2020.

Zwierzchowski E., Opozycja parlamentarna, [in:] E. Zwierzchowski (ed.), Opozycja parlamentarna, Warszawa 2010.

Zybertowicz A., Gurtowski M., Sojak R., Państwo Platformy. Bilans zamknięcia, Warszawa 2015.

Żukiewicz P., Przywództwo polityczne. Teoria i praktyka, Warszawa 2011. 